\title{
Bacillus mycoides improves health of gastrointestinal tract in marron (Cherax cainii, Austin 2002)
}

\begin{abstract}
The present study examined the health status of the gastrointestinal tract (GIT) in marron after a two-month feeding trial with a diet supplemented with host origin, Bacillus mycoides. Two groups of marron were fed with either a basal diet or probiotic added at $108 \mathrm{cfu} / \mathrm{g}$ of feed. Microbial density, microvilli length and number, intestinal epidermis layer morphology and hepatopancreas indices of weight and moisture content were evaluated. Supplementation with $B$. mycoides in marron feed significantly improved intestinal bacterial density $(4,007 \pm 121$ million cfu/g of GIT) compared to basal diet fed marron (723.7 \pm 45.2 million cfu/g of GIT). Microvilli density (per $100 \mu \mathrm{m}^{2}$ ) was also significantly higher $(10.50 \pm 0.25 \mu \mathrm{m})$ compared to $5.71 \pm 0.24$ in basal diet fed marron. Significantly higher villous length $(4.93 \pm 0.11 \mu \mathrm{m})$ was observed in probiotic fed compared to basal diet fed marron $(3.91 \pm 0.18 \mu \mathrm{m})$.
\end{abstract}

The intestinal epidermis layer of probiotic fed marron showed increased folding and thickness compared to basal diet fed marron. Higher hepatosomatic indices (Hiw) and low moisture content $(\mathrm{HM} \%)$ in probiotic fed marron indicated efficient functioning of the healthy gut. The present study suggests that supplementing host origin customised probiotic in feed improves gut health as measured by microbial density, microvilli length and number, intestinal epidermis layer and hepatosomatic indices.

Keywords: Probiotic, Microbial density, Microvilli, Hepatosomatic indices, Marron
Volume 2 Issue 2 - 2015

\author{
Irfan Ambas, ${ }^{1,3}$ Ravi Fotedar,' Nicky Buller ${ }^{2}$ \\ 'Department of Environment and Agriculture, Curtin University, \\ Bentley,WA, Australia \\ ${ }^{2}$ Department of Agriculture and Food South Perth,WA,Australia \\ ${ }^{3}$ Department of Fishery, Hasanuddin University, Km 10 Makassar \\ Indonesia 90225
}

Correspondence: Irfan Ambas, Sustainable Aquatic Resources and Biotechnology, Department of Agriculture and Environment, Curtin University, Bentley,WA, Australia, Tel +6I -8- 92664508, Emailirfanambas@yahoo.com

Received: December 0I, 20I4 | Published: April 25, 2015
Abbreviations: BA, Blood Agar; Cfu/g, Colony Forming Unit Per Gram; Cm, Centimetre; GIT, Gastrointestinal Tract; GLL, Glycerol Lab Lemco broth; H \& E, Hematoxylin and Eosin; Hiw and $\mathrm{H}_{\mathrm{id}}$, hepatosomatic wet and dry; $\mu \mathrm{m}$, micrometre; HMDS, Hexamethyldisilazane; (HM\%), Moisture Content; L, Litre; L/min, Litre/minute; M, Molar; MGA, Marron Growers Association; SEM, Scanning Electron Microscope; $\mathrm{W}_{\mathrm{wh}}$, Weight of wet hepatopancreas; $\mathrm{W}_{\mathrm{dh}}$, Weight of dry hepatopancreas; $\mathrm{W}_{\mathrm{t}}$, Total Weight of Marron

\section{Introduction}

It is widely established that in addition to skin and gills, the gastrointestinal tract (GIT) is considered one of the major routes for pathogenic invasion in aquatic animals. ${ }^{1-4}$ Therefore, study of the GIT of aquatic animals as a physical and immunological barrier is increasingly important, and it is accepted that digestion and immunity are complicated physiological processes that have co-evolved. ${ }^{4,5}$ The GIT of aquatic animals plays an important role in non-specific immune defences, as it provides an initial barrier to pathogen entry. ${ }^{5,6-10}$ The first step in bacterial invasion of the intestine is mediated by adhesion of pathogenic bacteria to mucosal surfaces and disruption of the microbial balance. ${ }^{7,11}$ In most fish hatcheries, intestinal microbial disorders caused by bacterial disease are considered to be a major cause of mortality, thus stability of the intestinal microbes and gut health are essential for the health of an organism..$^{10}$ As a result, much attention has been focused on the development of probiotics in order to maintain a stable, beneficial gut microbial population. ${ }^{12}$ Study of morphology and intestinal health of aquatic animals using prebiotics has been evaluated in red drum, Sciaenopsocellatus, ${ }^{13,14}$ rainbow trout, Oncorhynchus mykiss, ${ }^{15}$ gilthead sea bream, Sparusaurata, ${ }^{16}$ tilapia, Oreochromis niloticus,${ }^{17}$ channel catfish Ictalurus punctatus, ${ }^{18}$ Pacific white shrimp, Litopenaeusvannamei $i{ }^{19}$ marron Cherax tenuimanus ${ }^{20}$ and its combination with probiotic. ${ }^{4,21-24}$
Although the use of probiotics in aquatic animals has been reviewed by many authors, ${ }^{7,25-30}$ information for probiotics effect on intestinal health and morphology is extremely limited. ${ }^{18,31}$ To date, probiotic effects on intestinal health and morphology have been studied only in Nile tilapia, Oreochromis niloticus, ${ }^{32}$ seabream, Sparusaurata L. ${ }^{31}$ and beluga, Husohuso. ${ }^{33}$ Bacillus mycoides is a bacterium found in marron and the environment that has favourable probiotic properties including growth inhibition of $V$. mimicus and $V$. cholerae non-01, is susceptible to a majority of antibiotics, non-pathogenic to marron, produces a wide range of enzymes ${ }^{34}$ and improved the immunity and health of marron..$^{35}$ The aim of the present study was to examine the effects of Bacillus mycoides on intestinal health and morphology in marron $^{36}$ as determined by bacterial density, hepatopancreas indices including moisture content, microvilli density and length, and histological examination of intestinal cells.

\section{Materials and Methods}

\section{Culture system, experimental animal and feed preparation}

The experimental units were cylindrical plastic tanks $(80 \mathrm{~cm}$ diameter, $50 \mathrm{~cm}$ high and $250 \mathrm{~L}$ in capacity). The tanks were filled with freshwater and supplied with constant aeration, and sufficient number of marron shelters of PVC pipes with appropriate diameters. Each tank was also equipped with a submersible thermostat set to $24^{\circ} \mathrm{C}$ and a recirculating biological filtration system. The water in the tank was recirculated continuously at a rate of approximately $3 \mathrm{~L} /$ min. To maintain good water quality in the tanks, water exchange at a rate of $10-15 \%$ of the total water volume was performed twice a week, after siphoning out the faeces and uneaten feed. Marron (weight 33-65g) were obtained from the Marron Growers Association (MGA) in Northcliffe and Manjimup, Western Australia. The $250 \mathrm{~L}$ tanks were stocked with marron at a density of 12 marron/tank. Before 
commencement of the experiment, marron were kept for two weeks in the experimental tanks for acclimation. During the two month experimental period, a commercial pelleted diet $(26 \%$ protein, $47-$ $50 \%$ carbohydrate, $9 \%$ fats and $8.9 \%$ ash) from Enviroplus Pty Ltd., Perth Australia was fed to marron at a rate of $1.5 \%$ body weight per day. Bacillus mycoides was isolated from a number of healthy marron.

The isolate was identified by the Bacteriology Laboratory, Animal Health Laboratories, Department of Agriculture and Food, Western Australia, using a matrix-assisted laser desorption ionization timeof-flight (MALDI-TOF) mass spectrometer (Bruker Bioscience Corporation), Vitek Compact II (Biomerieux) and conventional biochemical methods according to standard procedures and identification methods. ${ }^{37}$ Subsequently, the strain was suspended into $1 \mathrm{~mL}$ aliquots of GLL (Glycerol Lab Lemco broth) and stored at $80^{\circ} \mathrm{C}$. Supplementation using the probiotic strain was performed as per Hai and Fotedar. ${ }^{21}$ In brief, prior to probiotic supplementation of the experimental diet, a pure culture of B. mycoides was grown on $5 \%$ horse blood agar (BA) plates for $24 \mathrm{~h}$ at $25^{\circ} \mathrm{C}$. Colonies in logarithmic phase of growth were emulsified in sterilised distilled water and serially diluted. The optical reading of each serial dilution was recorded, and a viable count performed to obtain a standard curve for inoculum density. From the standard curve, the amount of the diluted probiotic was calculated to achieve the desirable supplementation density of $10^{8}$ colony forming unit (cfu) per gram of feed. The pellets were air dried, packed and stored at $4^{\circ} \mathrm{C}$ until used.

\section{Data collection}

At the termination of the experiment, the GIT health status of marron was determined through analysis of bacterial density, microvilli length and density, histologic assessment of GIT epithelium, and moisture content and weight of the hepatopancreas. All animals used for analysis from both treatment groups were of equal in weight or length size in order to minimise misinterpretations due to size variations.

Bacterial density: The bacterial density of marron GIT after feeding with probiotic supplemented feed was measured at the beginning and end of the experiment. Ten marron from each treatment group were sacrificed by placing them at $-20^{\circ} \mathrm{C}$ for 5 minutes before aseptic removal of the GIT. The marron dorsal shell was cut-off horizontally from tail to head until the hepatopancreas and intestine were exposed. The hepatopancreas was removed, placed in a sterilised pestle, weighed and then homogenised. Similarly, the intestine from individual animals was collected aseptically and homogenised with a micropestle in a $1.5 \mathrm{ml}$ microfuge tube. The homogenised hepatopancreas, and the homogenised intestine were serially $\left(10^{-1}\right.$, $10^{-2}, 10^{-3}, 10^{-4}, 10^{-5}$ and $10^{-6}$ ) diluted. Fifty microliter of each serial dilution was inoculated onto a BA plate and incubated overnight in a $\mathrm{CO}_{2}$ incubator at $25^{\circ} \mathrm{C}$. A colony count was performed for each dilution to determine the total number of aerobic bacteria.

GIT microvilli assessment by micrograph: The distal part of the marron intestine was observed using a scanning electron microscope (SEM) following an established method. ${ }^{38,39}$ The intestinal tract of five marron from each treatment group was dissected and immersed in $3 \%$ glutaraldehyde in $0.1 \mathrm{M}$ cacodylate buffer overnight. Following overnight immersion, the GIT was washed in 3 change softhe cacodylate buffer and 3 changes in distilled water for $5 \mathrm{~min}$ per change. The intestine was immersed in $2 \% \mathrm{OsO}_{4}$ for $2 \mathrm{~h}$ followed by 3 washes in distilled water for $5 \mathrm{~min}$ per wash. Dehydration of the sample was performed through solutions of $50 \%, 75 \%, 95 \%$ ethanol for $5 \mathrm{~min}$ per solution and finally 3 times in $100 \%$ ethanol for $5 \mathrm{~min}$ per change followed by chemical drying by washing in a series of $50 \%, 75 \%$ and $100 \%$ (twice) hexamethyl disilizane (HMDS) in ethanol solutions for 5 min per change. The final stage involved drying the samples at room temperature, mounting on as tub using carbontape and then coating with gold before viewing the samples under a pressure scanning electron microscope (LX30). The images obtained from SEM were used to describe villous height and density (number per group surface area) in the GIT. The height of microvilli $(\mu \mathrm{m})$ was measured following established methods. ${ }^{31,32}$ At least 10 villous per section were randomly selected and measured using a computerised morphometric technique. The height of each villous was measured from the villous bottom to the tip, and the average height of these 10 villi was expressed as the mean villous height. Villous density (villous/100 $\mu \mathrm{m}$ surface area) and villi per group were counted according to Sang and Fotedar. ${ }^{39}$

Histological assessment of the intestine: Histological preparation and assessment of marron GIT post-feeding with probiotic and basal diets were prepared by Animal Health Laboratories, Department of Agriculture and Food Western Australia. Five marron GIT from each treatment group were dissected and fixed in $10 \%$ buffered formalin for $24 \mathrm{~h}$. Dehydration of the tissue was performed by passing through a series of $70 \%, 85 \%$ and $98 \%$ alcoholsolutions. The samples were vacuum embedded in paraffin. The histological sections of $4-5 \mu \mathrm{m}$ was stained with Hematoxylin andeosin (H\&E). The sections were examined and photographed using an Olympus BX50 microscope.

Hepatosomatic indices (HiW): The hepatosomatic indices (Hiw) of marron fed with probiotic supplemented diet and basal diet were calculated as per established equations. ${ }^{40,41}$ In brief, the hepatopancreas of ten marron from each treatment group were removed placed in foil and weighed. For hepatopancreas moisture content, the hepatopancreas was dried at $110^{\circ} \mathrm{C}$ for $24 \mathrm{~h}$. The results, expressed as wet hepatosomatic indices (Hiw), dry hepatosomatic indices $\left(\mathrm{H}_{\mathrm{id}}\right)$ and hepatopancreas moisture content (HM) were calculated as follows;

$$
\begin{gathered}
\text { Hiw }=W_{w h} \times 100 W_{t-}{ }^{l} \\
\text { Hid }=W_{d h} \times 100 W_{t-}{ }^{1} \\
H M=\left(W_{w h}-W_{d h}\right) \times 100 W_{w h}{ }^{-1}
\end{gathered}
$$

Where;

Hiw: Wet hepatosomatic indices (\%)

Hid: Dry hepatosomatic indices (\%)

$\mathrm{W}_{\mathrm{wh}}$ : Weight of wet hepatopancreas (g)

$\mathrm{W}_{\mathrm{dh}}$ : Weight of dry hepatopancreas

$\mathrm{W}_{\mathrm{t}}$ : Total weight of marron $(\mathrm{g})$

HM: Hepatopancreas moisture content (\%)

Data analysis

Data were analysed using SPSS statistical program version 22. Comparison of the mean values using T-test was performed to determine significance and the results were presented in tables 1-3 and graphs.

\section{Results and Discussion}

\section{Results}

Bacterial density: The mean bacterial density in marron intestine fed probiotic supplemented diet was significantly increased ( $4007 \pm 121$ million cfu/g of GIT) compared to the bacterial density in 
the gut of basal diet fed marron (723.7 \pm 45.2 million $\mathrm{cfu} / \mathrm{g}$ of GIT). The diversity of the bacterial population was greater in the GIT of probiotic supplemented diet fed marron compared to basal diet fed, as observed by colonial morphology on BA plates after $24 \mathrm{~h}$ incubation at $25^{\circ} \mathrm{C}$ (Figure 1).

Table I Ingredients of the basal diet

\begin{tabular}{|c|c|}
\hline Ingredients & Percentage (\%) \\
\hline Wheat Flour & 49.35 \\
\hline Fish Meal ${ }^{\mathrm{a}}$ & 33.78 \\
\hline Soybean Meal & 10.15 \\
\hline Fish Oilb & 3.2 \\
\hline Wheat Starch & 1.85 \\
\hline Betaine $^{c}$ & 1.20 \\
\hline Cholesterol & 0.25 \\
\hline Premix ${ }^{d}$ & 0.15 \\
\hline Ascorbic Acid & 0.05 \\
\hline Calcium Carbonate & 0.02 \\
\hline Total & 100 \\
\hline
\end{tabular}

All ingredients were supplied by Specialty Feeds Pty LtdWA, Australia.

aPeruvian fishmeal, 56 \% CP

${ }^{b}$ Cod liver oil

'Betaine anhydrous $97 \%$

${ }^{\mathrm{d}}$ Commercial vitamin and mineral premix for trout

Table 2 Mean \pm SE $(n=5)$ of villous height $(\mu \mathrm{m})$, villous number per group and villous density (per $100 \mu \mathrm{m}^{2}$ ) of marron hindgut fed probiotic supplemented diet and basal diet

\begin{tabular}{lll}
\hline Parameters & Probiotic Diet & Basal Diet \\
\hline Villous Height & $4.93 \pm 0.1 \mathrm{I}^{\mathrm{b}}$ & $3.91 \pm 0.18^{\mathrm{a}}$ \\
Villous Per Group & $10.50 \pm 0.25^{\mathrm{b}}$ & $5.7 \mathrm{I} \pm 0.24^{\mathrm{a}}$ \\
Villous Density & $20.28 \pm 0.70^{\mathrm{b}}$ & $13.93 \pm 0.4^{\mathrm{a}}$ \\
\hline
\end{tabular}

*Mean value in the same row having different superscript indicates significantly differentat $\mathrm{P}<0.05$

Table 3 Mean \pm SE $(n=10)$ of hepatosomatic indices (\%) and moisture content (\%) of marron fed basal and probiotic supplemented diet

\begin{tabular}{llll}
\hline Treatment & Hiw (\%) & Hid (\%) & HM (\%) \\
\hline Basal diet & $6.20 \pm 0.02^{\mathrm{a}}$ & $2.71 \pm 0.06^{\mathrm{a}}$ & $62.16 \pm 1.09^{\mathrm{a}}$ \\
Probiotic diet & $7.11 \pm 0.34^{\mathrm{b}}$ & $3.32 \pm 0.25^{\mathrm{b}}$ & $53.43 \pm 1.68^{\mathrm{b}}$ \\
\hline
\end{tabular}

*Mean values in the same column with different superscript indicate significantly different $(P<0.05)$

Hiw: hepatosomatic indices (wet)

Hid: hepatosomatic indices (dry)

HM: Hepatopancreas moisture content

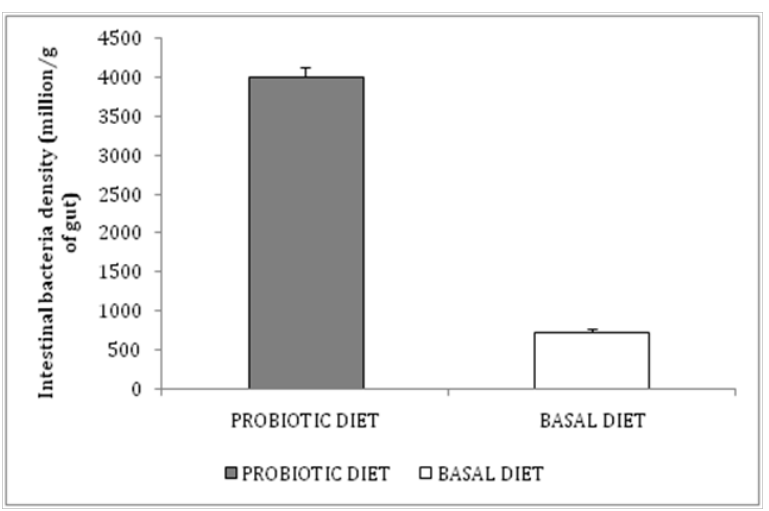

Figure I Mean $\pm S E(n=10)$ of intestinal bacteria population (million/g of gut) of marron fed basal and probiotic supplemented diet.

\section{GIT microvilli assessment by micrograph}

The morphology of marron intestines after feeding with probiotic supplemented diet compared to basal diet is shown in Figure 2. The density and length of the microvilli per GIT surface area was significantly higher in marron fed B. mycoides supplemented diet (A) than microvilli of basal diet fed marron (B). The average density of microvilli per group (number of villous in a row) of marron fed the probiotic diet was $10.50 \pm 0.94$ compared to $5.71 \pm 0.91$ in basal diet fed marron (Figure 3).

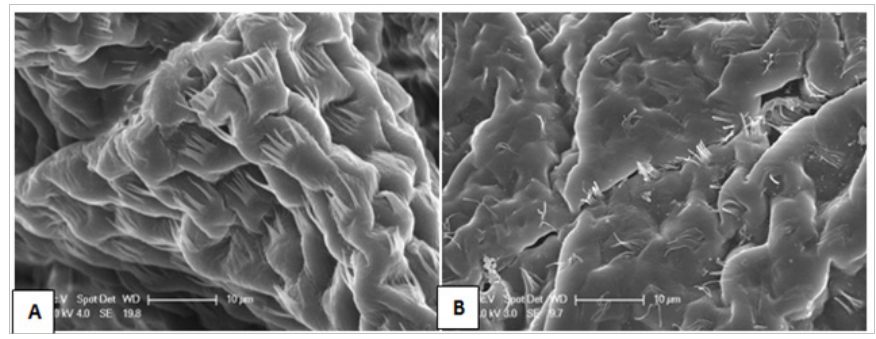

Figure 2 Scanning electron microscopy micrograph of marron hindgut fed probiotic supplemented $\operatorname{diet}(A)$ and basal diet $(B) .(x=2500$. Bar=10 $\mu \mathrm{m})$. In the probiotics fed marron there is an increase in folds and the villi are longer and more numerous.
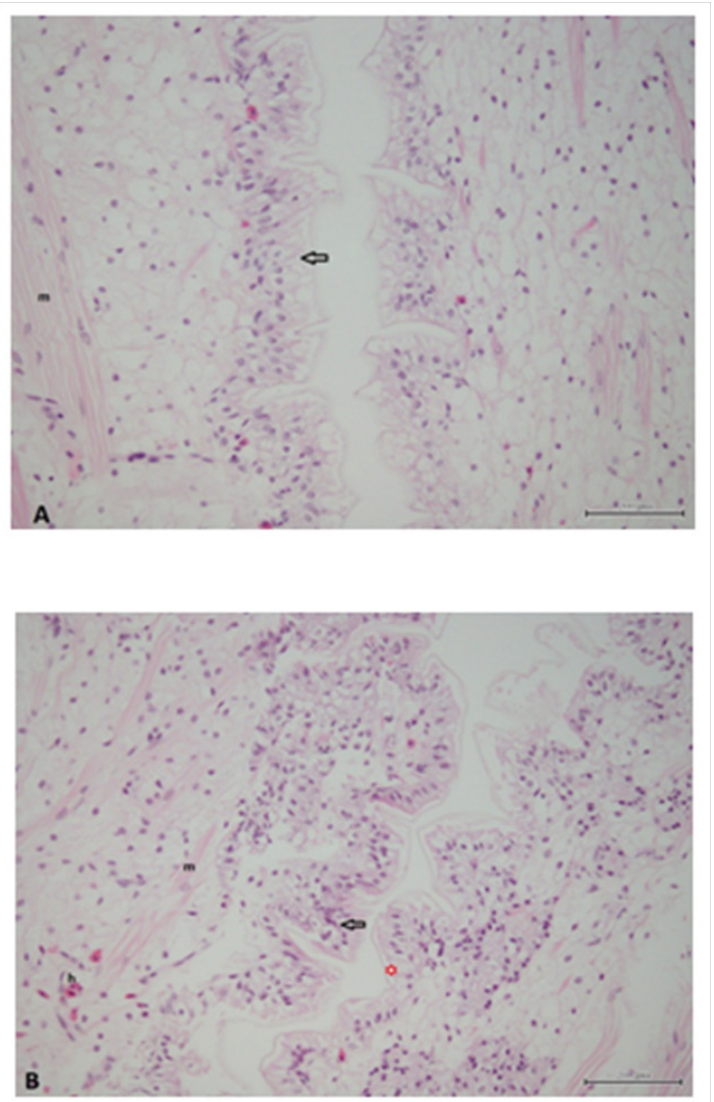

Figure 3 Histological sections of the hindgut from marron fed the control diet (A) and the probiotic supplemented diet (B). The epidermal cells (open arrow) in the probiotic supplemented group are larger and have a more foamy appearance. In both treatments there is some shrinkage artifact of the cuticle from the epithelial cells (red star). Muscle cells $(\mathrm{m})$ and mixed populations of haemocytes $(\mathrm{h})$ can be seen in the lamina propria in both the control and probiotic supplemented animals. Bars indicate $200 \mu \mathrm{m}$.

Histological assessment of intestine: Histologically there were no major differences seen in the hepatopancreas of marron from the 
different treatment groups. However, the foregut and hindgut of the probiotic fed marron had more folds and fewer haemocytes compared to the marron fed the control diet without probiotics.

Hepatopancreas weight: Hepatosomatic indices (Hiw) of probiotic fed marron were significantly higher $(7.11 \pm 0.34)$ compared to basal diet fed marron (6.20 \pm 0.02$)$. In addition, hepatopancreas moisture content $(\mathrm{HM} \%)$ was lower $(53.43 \pm 1.68 \%)$ in probiotic fed marron whereas in basal diet fed marron it was $62.16 \pm 1.09 \%$.

\section{Discussion}

Balcazar et al. ${ }^{42}$ Zhou and Wang ${ }^{43}$ suggest that probiotics act in several ways: Firstly by maintaining and restoring normal intestinal microbiota and gut homeostasis; secondly by contributing to the competitive exclusion of bacteria $\mathrm{a}^{4-47}$ and thirdly by acting as a source of nutrients and enzymes. ${ }^{7,48-52}$ Most authors suggest that probiotics of host origin are more favourable compared to other sources as is believed that autochthonous bacteria are able to colonise, multiply and remain predominant in the same host. ${ }^{7,10,25,53,54}$ The health status of the GIT is most likely determined by the microbial balance of indigenous microbiota ${ }^{49,55}$ with the density and diversity of bacteria in the intestine having the most impact on intestinal health. ${ }^{56}$ The main parameters commonly used to assess GIT health in aquatic animals are intestinal bacterial density and diversity, microvilli height and number, gut epithelium, hepatopancreas size and digestive enzyme activity. ${ }^{4,15,31,36,39,56-58}$

In the present study marron fed a diet supplemented with Bacillus mycoides had improved intestinal morphology, increased density of bacteria in the intestine and a heavier hepatopancreas. All of these features suggest that the marron benefited from the probiotic supplementation. A number of studies show intestinal bacteria density increases after probiotic supplementation which is thought to be due to a probiotic of host origin providing a favourable environment for the indigenous intestinal bacteria. In shrimp Penaeusmonodon, the number of intestinal bacteria increased by up to $803 \%$ after supplementation with three Bacillus species (B. pumilus, B. sphaericus, and B. subtilis) isolated from the host. ${ }^{59}$ In grouper Epinepheluscoioides potentially beneficial bacteria were stimulated, whereas some potentially harmful strains such as Staphylococcus saprophyticus, were suppressed after supplementation with probiotic Psychrobacter sp. ${ }^{60}$ Reduction of either diversity or quantity of the indigenous microbiota is likely to reduce the effective barrier mechanism normally provided by the commensal microbiota. ${ }^{11,55}$

Another feature of a healthy digestive system is the density and length of microvilli. In the present study, supplementation with $B$. mycoides significantly improved the height and number of villi. Other studies on probiotics had similar findings including one on marron using mannan-oligosaccharide (MOS) diet, ${ }^{20}$ and others using Lactobacillus sp. in Nile tilapia Oreochromis niloticus, ${ }^{32}$ Bacillus $\mathrm{sp}$. in European lobster Homarusgammarus L. ${ }^{24}$ and Pedicoccus acidilactici in rainbow trout. ${ }^{61}$ Contrary to these findings, observed no improvements in microvilli in rainbow trout fed with Bacillus sp. or Enterococcus faecium supplemented feeds, whereas Cerezuela et al. ${ }^{34}$ found shorter villi in gilthead seabream (Sparusaurata) fed diets containing B. Subtilise, suggesting that the effect of probiotics on microvilli may not be consistent in all species.

In aquatic animals, longer intestinal villi provide greater absorption ability due to their increased surface area. ${ }^{26,34,35,62}$ They also provide a larger surface area for bacterial colonisation as was reported for Arctic charr, Salvelinusalpinus. Ringo et al. ${ }^{63}$ observed large populations of bacteria associated with the villous brush borders, while Hellberg and Bjerkas ${ }^{64}$ detected the bacteria between the microvilli in common wolfish, Anarhichas lupus (L). In addition, Merrifield et al. ${ }^{65}$ observed greater bacterial colonization between the folds of the mucosal surface because bacteria could become established and sustained more easily at the base of the villi and between the mucosal folds. Merrifield ${ }^{23}$ suggested that more dense and regular villi may also play a role in disease prevention by reducing exposure to enterocyte tight junctions in rainbow trout, Oncorhynchus mykiss (Walbaum). Various hepatosomatic indices of marron have been reported in several studies. Jussila ${ }^{66}$ compared hepatosomatic indices of marron at molt and postmolt at different feeding status and found that the lowest (3.8 $\pm 0.2 \%)$ hepatosomatic indices (Hiw) of marron was observed in non-fed postmolt marron, followed by fed post-molt marron $(5.4 \pm 0.3 \%)$ and the highest $(5.6 \pm 0.3 \%)$ in fed-intermolt stage marron.

Sang and Fotedar ${ }^{67}$ observed Hiw of marron fed $\beta-1,3$ glucan supplemented diet ranged between $6.35-7.17 \%$. In the present study Hiw of probiotic fed marron was $7.11 \pm 0.34 \%$ compared to $6.20 \pm$ $0.02 \%$ for basal diet fed marron. The improved intestinal health in the probiotic fed marron most likely resulted in the higher hepatosomatic index of these marron. The hepatopancreas, as the main energy reserve in crustaceans and source of various enzymes, has been used as an indicator of crayfish condition [40,41]. A heavier hepatopancreas could be an indication of higher digestive enzyme activities. ${ }^{68}$ Our previous study also indicated that marron fed B. mycoideshad a larger hepatopancreas especially at day $35 .^{35}$ B. mycoides produces a wide range of enzymes ${ }^{34}$ including many exo-enzymes important for digestion $^{69}$ and is a reason why Bacillus sp. have been used widely as probiotics. ${ }^{70}$

\section{Conclusion}

Overall, supplementation of host origin B. mycoides in marron feed improved the health of the marron gastrointestinal tract as indicated by an increase in bacterial density, increased and longer microvilli, thicker intestinal epithelium and higher hepatosomatic indices. Consequently the use of host origin (particularly mucosal inhabitants) strains of bacteria with probiotic properties is recommended as these bacteria are able to maintain microbial homeostasis, are well adapted to the host GIT environment and mucosal attachment, and can protect the epithelium layer from potential pathogens, which in turn preserve optimal function of the gastrointestinal tract.

\section{Acknowledgements}

The authors wish to thank Directorate General of Higher Education (DIKTI) of Indonesia which financially supported this study. Sincere gratitude to Dr. Fran Stephens and Mr. Tai Le from Animal Health Laboratories, Department of Agriculture and Food Western Australia for histological samples preparation and analysis. Mr. Le TrungKy for SEM samples preparation, Mr. and Mrs. Harris for the supply of marron and Mr Albert Cooper for proof-reading of the manuscript.

\section{References}

1. Melloul A, Collin M Key natural and anthropogenic parameters enhancing the effect of sea level rise: The case of Israel's Mediterranean coast. Ocean \& Coastal Management. 2009;52(1):39-46.

2. Field CB, Mortsch LD, Brklacich M, Forbes DL, Kovacs P, et al. North America. In: Parry ML, et al. (Eds), Climate Change 2007: Impacts, Adaptation and Vulnerability. Contribution of Working Group II to the Fourth Assessment Report of the Intergovernmental Panel on Climate Change. Cambridge University Press, Cambridge, UK, pp. 2007;617- 
652.

3. CCSP (Coastal Sensitivity to Sea-Level Rise: A Focus on the MidAtlantic Region A report by the U.S. Climate Change Science Program and the Subcommittee on Global Change Research. US Environmental Protection Agency, Washington, DC, USA. 2009;

4. Karl TR, Melillo JM, Peterson TC Global climate change impacts in the United States. Cambridge: Cambridge University Press. 2009

5. IPCC (Climate Change 2007: impacts, adaptation and vulnerability. Contribution of working group II to the fourth assessment report of the intergovernmental panel on climate change. Cambridge University Press, Cambridge, UK, pp. 2007; 976.

6. Church JA, White NJ (A $20^{\text {th }}$ century acceleration in global sea level rise. Geophysical Research Letters. 2006;33(1):1-4.

7. Lambeck K, Anzidei M, Antonioli F, Benini A, Esposito A (Sea level in Roman time in the Central Mediterranean and implications for recent change. Earth and Planetary Science Letters. 2004;224 563-575.

8. Nicholls RJ Small C Improved estimates of coastal population exposure to hazards released. EOS Transactions. 2002;83(28):303-305.

9. IOC/UNESCO, IMO, FAO, UNDP x A Blueprint for Ocean and Coastal Sustainability. IOC/UNESCO, Paris. 2002

10. Nicholls RJ, Tol RSJ Impacts and responses to sea-level rise: A global analysis of the SRES scenarios over the twenty-first century, Philosophical Transactions of the Royal Society. 2006;A 364:1073.

11. Marbaix P, Nicholls RJ Accurately determining the risks of rising sea level, EOS Transactions. 2007; 88(43):441-442.

12. Travers A, Elrick C, Kay R Background Paper: Climate Change in Coastal Zones of the Mediterranean. Priority Actions Programme, Mediterranean Regional Activity Centre, Coastal Zone Management Pty Ltd, Claremont, Australia. 2010

13. European Commission Sustainability Report. Luxemburg: Office for Official Publications of the European Communities, pp. 160.2009

14. Carillo A, Sannino G, Artale V, et al. Steric sea level rise over the Mediterranean Sea: present climate and scenario simulations. Climate Dynamics. 2012;39(9/10):2167-2184.

15. Tsimplis $\mathrm{MN}$, Marcos M, Colin J, et al. Sea level variability in the Mediterranean Sea during the 1990s on the basis of two 2D and one 3d model. Journal of Marine Systems. 2009;78(1):109-123.

16. Tsimplis MN, Baker TF Sea level drop in the Mediterranean Sea: An indicator of deepwater salinity and temperature changes? Geophysical Research Letters. 2000;27(12):1731-1734.

17. Paulopoulos K, Chalkias C, Karimbalis E Potential impact of sea level rise on Mykonos, Delos, Rinia islands, In: 6th Pan-Hellenic Geographical Conference, Thessaloniki, pp. 2002;3:469-476.

18. EUROSTAT Coastal regions. In: Asa Onnerfors (Ed.), Eurostat regional yearbook 2011. Luxembourg: Publications Office of the European Union, Belgium. 2011
19. Coudert E, Larid M IMAGINE: un ensemble de méthodes et d'outils pour contribuer à la gestion intégrée des zones côtières en Méditerranée, Vertigo-la revue électronique en sciences de l'environnement, Dossier : Les littoraux et la gestion intégrée des zones côtières. 2006; 7(3).

20. Devoy RJN (Coastal Vulnerability and the Implications of Sea-Level Rise for Ireland. Journal of Coastal Research. 2008;24(2):325-341.

21. Barth MC, Titus JG Greenhouse effect and sea level rise: A challenge for this generation, Van Nostrand Reinhold, New York, USA. pp. 1984; 324.

22. Milliman JD, Broadus JM, Gable F Environmental and economic implications of rising sea level and subsiding deltas: The Nile and Bengal examples. Ambio. 1989;18(6):340-345.

23. Warrick RA, Barrow EM, Wigley TML (Climate and sea level change: Observations, projections, implications. Cambridge University Press, Cambridge. 1993

24. IPCC (Climate change 2001: impacts, adaptation and vulnerability. Contribution of the working group to the $3 \mathrm{rd}$ assessment report of the intergovernmental Panel on Climate Change. World Meteorological Organization, Geneva, pp. 2001;124.

25. IPCC Climate change 2001: impacts, adaptations and vulnerability. In: McCarthy JJ, et al. (Eds.), Contribution of Working Group II to the Third Assessment Report of the Intergovernmental Panel on Climate Change. Cambridge University Press, Cambridge, p. 2001; 75.

26. National statistical Survey of Greece Population, housing and buildings Census 2001,p. 2003;18

27. Dubois RN How does a barrier shoreface respond to a sea-level rise? Journal of Coastal Research. 2002; 18:2.

28. Bruun $\mathrm{P}$ (Sea-level rise as a cause of shore erosion. Journal of Waterways and Harbors Division: 1962; 117-130.

29. Rahmstorf S, Foster G, Cazenave A (Comparing climate projections to observations up to 2011. Environmental Research Letters. 2012;7: 4.

30. Al-Buloshi A, Al-Hatrushi S, Charabi Y GIS-based Framework for the Simulation of the Impacts of Sea Level Rise and Coastal Flooding on Oman. Journal of Earth Science \& Climatic Change. 2014; 5(10): 1-6.

31. Neumann JE, Hudgens DE, Herter J, Martinich J Assessing Sea-Level Rise Impacts: A GIS-Based Framework and Application to Coastal New Jersey. Coastal Management. 2010;38(4):433-455.

32. Nicholls RJ, Tol RSJ, Vafeidis AT (Global estimates of the impact of a collapse of the West Antarctic ice sheet: an application of FUND. Climatic Changes. 2008;91(1-2):171-191.

33. Valiela I Global coastal change. Wiley-Blackwell, London, pp. 2006; 376.

34. Dasgupta S, Laplante B, Meisner C, Wheeler D, Yan J (The impact of sea level rise on developing countries: a comparative analysis. Climatic Change. 2009;93(3-4):379-388.

35. Nicholls RJ Coastal flooding and wetland loss in the $21^{\text {st }}$ century: changes under the SRES climate and socio-economic scenarios. Global Environmental Changes. 2004;14(1):69-86. 